Article

\title{
Anti-Inflammatory Functions of Methanol Extract from Malus baccata (L.) Borkh. Leaves and Shoots by Targeting the NF-kB Pathway
}

\author{
Chaoran Song ${ }^{1}$, Hongxi Chen ${ }^{1}{ }^{1}$, Soo Ah Kim ${ }^{2}$, Jong Sub Lee ${ }^{2}$, Eui Su Choung ${ }^{2}$, Zhiyun Zhang ${ }^{3}$, \\ Soo-Yong Kim ${ }^{4}$, Jong-Hoon Kim ${ }^{5, *}$ and Jae Youl Cho ${ }^{1, *}$
}

Citation: Song, C.; Chen, H.; Kim, S.A.; Lee, J.S.; Choung, E.S.; Zhang, Z.; Kim, S.-Y.; Kim, J.-H.; Cho, J.Y. Anti-Inflammatory Functions of Methanol Extract from Malus baccata (L.) Borkh. Leaves and Shoots by Targeting the NF- $\kappa$ B Pathway. Plants 2022, 11, 646. https://doi.org/ 10.3390/plants11050646

Academic Editors: Maria João Rodrigues and Catarina Guerreiro Pereira

Received: 26 January 2022

Accepted: 21 February 2022

Published: 26 February 2022

Publisher's Note: MDPI stays neutral with regard to jurisdictional claims in published maps and institutional affiliations.

Copyright: (C) 2022 by the authors. Licensee MDPI, Basel, Switzerland. This article is an open access article distributed under the terms and conditions of the Creative Commons Attribution (CC BY) license (https:// creativecommons.org/licenses/by/ $4.0 /)$.
1 Department of Integrative Biotechnology, Biomedical Institute for Convergence at SKKU (BICS), Sungkyunkwan University, Suwon 16419, Korea; songchaoran115@163.com (C.S.); chenhx19@gmail.com (H.C.)

2 DanjoungBio Co., Ltd., Wonju 26303, Korea; sa.kim@danjoungbio.com (S.A.K.); js.lee@danjoungbio.com (J.S.L.); esavella@hanmail.net (E.S.C.)

3 State Key Laboratory of Systematic and Evolutionary Botany, Institute of Botany, The Chinese Academy of Sciences, Beijing 100093, China; zhangzy@ibcas.ac.cn

4 International Biological Material Research Center, Korea Research Institute of Bioscience and Biotechnology, Daejeon 34141, Korea; soodole@kribb.re.kr

5 College of Veterinary Medicine, Chonbuk National University, Iksan 54596, Korea

* Correspondence: jhkim1@chonbuk.ac.kr (J.-H.K.); jaecho@skku.edu (J.Y.C.); Tel.: +82-63-270-2563 (J.-H.K.); +82-31-290-7868 (J.Y.C.)

\begin{abstract}
Malus baccata (L.) Borkh. is a widely used medical plant in Asia. Since the anti-inflammatory mechanism of this plant is not fully understood, the aim of this study was to explore the antiinflammatory function and mechanism of Malus baccata (L.) Borkh. methanol extract (Mb-ME). For in vitro experiments, nitric oxide production assay, PCR, overexpression strategy, immunoblotting, luciferase reporter assay, and immunoprecipitation were employed to explore the molecular mechanism and the target proteins of $\mathrm{Mb}-\mathrm{ME}$. For in vivo experiments, an $\mathrm{HCl} / \mathrm{EtOH}$-induced gastritis mouse model was used to confirm the anti-inflammatory function. Mb-ME showed a strong ability to inhibit the production of nitric oxide and the expression of inflammatory genes. Mb-ME decreased NF-кB luciferase activity mediated by MyD88 and TRIF. Moreover, Mb-ME blocked the activation of Src, Syk, p85, Akt, p50, p60, IKK $\alpha / \beta$, and IkB $\alpha$ in LPS-induced RAW264.7 cells. Overexpression and immunoprecipitation analyses suggested Syk and Src as the target enzymes of $\mathrm{Mb}-\mathrm{ME}$. In vitro results showed that $\mathrm{Mb}-\mathrm{ME}$ could alleviate gastritis and relieve the protein expression of $\mathrm{p}-\mathrm{Src}$, $\mathrm{p}-\mathrm{Syk}$, and COX-2, as well as the gene expression of COX-2 and TNF- $\alpha$. In summary, this study implied that $\mathrm{Mb}-\mathrm{ME}$ performs an anti-inflammatory role by suppressing Syk and Src in the NF- $\mathrm{KB}$ signaling pathway, both in vivo and in vitro.
\end{abstract}

Keywords: Malus baccata (L.) Borkh.; anti-inflammatory; NF-кB

\section{Introduction}

Inflammation is a crucial immune response that protects our bodies from diverse pathogens. When microorganisms such as Gram-negative bacteria with lipopolysaccharide (LPS) invade a human body, an innate immune response will be initiated within a few hours. Upon injury and infection, immune cells use pattern recognition receptors (PRRs) to sense exogenous infectious ligands whose molecular structures are broadly shared by pathogens and endogenous molecules that are released from dying and damaged cells [1]. Toll-like receptors (TLRs), well-characterized members of PRRs, are a membrane-bound protein $[2,3]$. Possessing the Toll-interleukin receptor (TIR) domain, four adaptor proteins are able to be recruited by TLRs: MyD88, TRIF, TIRAP, and TRAM [4,5]. The interactions between adaptor proteins and TLRs trigger transforming growth factor beta-kinase 1 (TAK1), 
leading to the activation of IKK complex-NF- $\mathrm{kB}$ and mitogen-activated protein kinases [6]. Consequently, extracellular signals are transduced through transcription factors, including NF- $\mathrm{kB}$, JAK-STAT, and AP-1 [7,8]. Subsequently, the translocation of transcription factors is elicited. Ultimately, these processes lead to the elevated release of inflammatory cytokines; chemokines; and IFNs, such as iNOS, interleukins, and TNF- $\alpha$, to protect the host from microbial infection [9-12]. Although inflammation is a vital process, uncontrolled and excessive inflammatory responses contribute to serious illnesses, such as diabetes, cancer, rheumatoid arthritis, and Alzheimer's disease [12-14]. Therefore, there is an urgent demand to develop highly effective and safe anti-inflammatory drugs.

Malus baccata (L.) Borkh. is a common plant mainly found in China, Russia, and Korea. It has a small edible fruit with traditional medicinal properties. Extracts of Malus baccata exhibit considerable amounts of bioactive components, such as flavonoids; anthocyanins of a-sitosterol and ursolic acid; and fatty acid molecules of palmitic acid, ethyl palmitate, and linolein [15-17]. The ethanol extract from the leaves of Malus baccata has been reported to contain inhibitors of fatty acid synthase (FAS), which can reduce body weight in vitro [18]. In addition, phenolic ingredients in the fruits of Malus baccata could significantly enhance immunomodulation activity and protect spleen cells from radiation-caused damage by regulating apoptosis [19]. Juices prepared from Malus baccata showed a strong inhibitory effect on proliferation in HL-60 human leukemia cells and strong DPPH radical scavenging activity [20]. There is little evidence that methanol extract from Malus baccata (Mb-ME) has the potential to inhibit excessive inflammation responses, necessitating the present study. In addition, the anti-inflammatory function and mechanism of this plant have not been fully elucidated yet. Therefore, in this study, we aimed to explore in vitro and in vivo anti-inflammatory activities of $\mathrm{Mb}-\mathrm{ME}$ and understand its molecular action mechanism through the verification of target protein(s).

\section{Results}

\subsection{Effect of $M b-M E$ on Nitric Oxide Production}

Nitric oxide is a molecule that plays a crucial role in inflammation [21]. Therefore, we investigated nitric oxide production upon LPS stimulation. The production of nitric oxide was downregulated by Mb-ME in a dose-dependent manner in RAW264.7 cells and peritoneal macrophages (Figure 1A,B). Results also showed that the standard compound L-NAME inhibited in a dose-dependent manner the secretion of nitric oxide under the same conditions both in RAW264.7 cells and in peritoneal macrophages (Figure 1C,D) without cytotoxicity (Figure 1F). Similarly, Mb-ME showed no obvious cytotoxicity in three cell lines (RAW 264.7 cells, HEK293 cells, and peritoneal macrophage cells) (Figure 1E). Finally, HPLC analysis was performed to identify the flavonoids in Mb-ME. Quercetin and hesperidin (upper panels in Figure 1G,H), showing the same retention times (6.05 and $22.02 \mathrm{~min}$, respectively) with their standard compounds (bottom panels in Figure 1G,H), were present in Mb-ME (Figure 1G,H). The content of hesperidin is $130.13 \mathrm{mg} / \mathrm{g}$, while the content of quercetin is only $0.28 \mathrm{mg} / \mathrm{g}$.

\subsection{Effect of $M b-M E$ on the $m R N A$ Expression of Inflammatory Genes}

To assess whether the decreasing trend of nitric oxide production was modulated by $\mathrm{Mb}-\mathrm{ME}$ at the transcriptional level, the pro-inflammatory genes were investigated using PCR in LPS-induced conditions. In Figure 2A,B, semi-quantitative RT-PCR results showed that the expression of iNOS, IL-1 $\beta$, IL-6, TNF- $\alpha$, MMP9, and COX- 2 was strongly stimulated by LPS treatment, while the expression was decreased in the presence of Mb-ME in a dosedependent manner, especially at the concentration of $100 \mu \mathrm{g} / \mathrm{mL}$. As expected, similar results were revealed by a quantitative RT-PCR. Mb-ME significantly blocked LPS-elevated expression levels of TNF- $\alpha$, iNOS, and IL-6 (Figure 2C-E). 


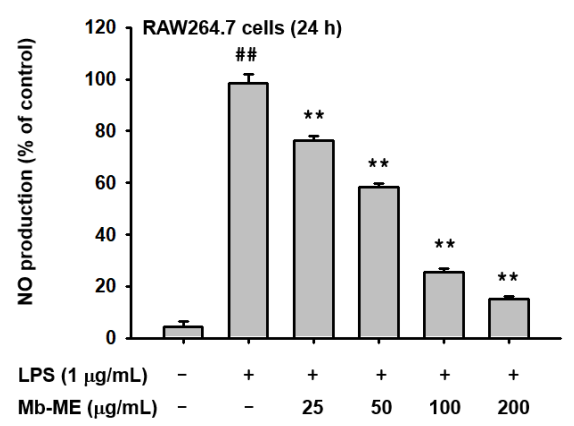

(A)

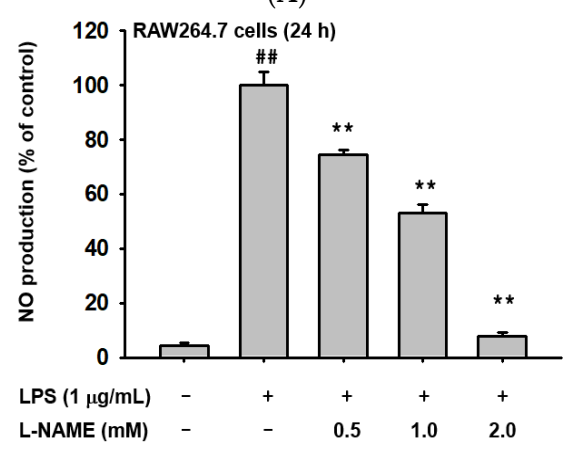

(C)

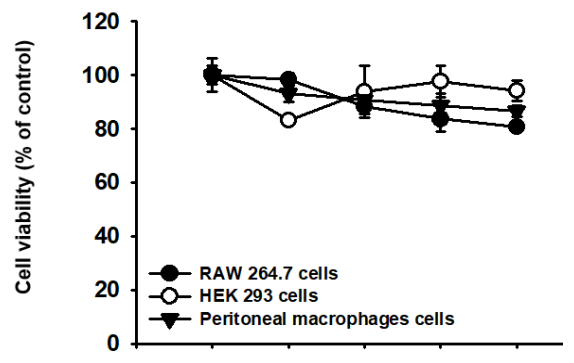

$\operatorname{Mb}-M E(\mu \mathrm{g} / \mathrm{mL}) \quad-\quad 25 \quad 50 \quad 100 \quad 200$

(E)

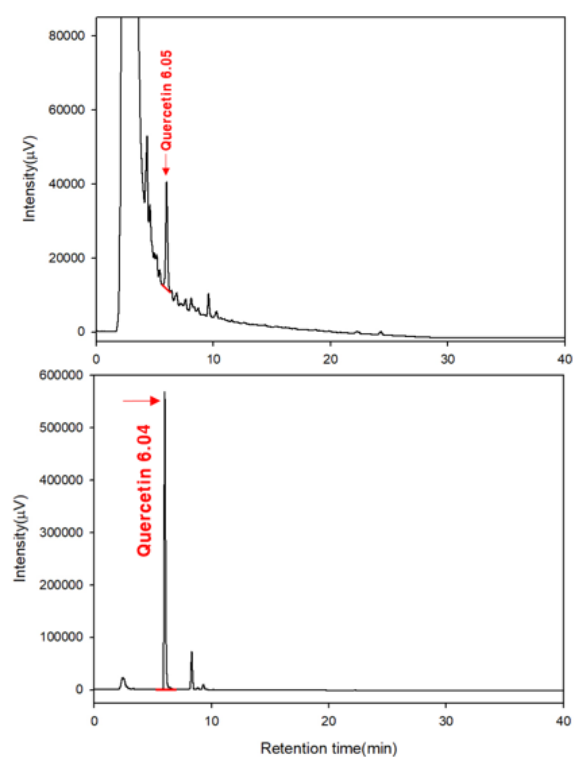

(G)

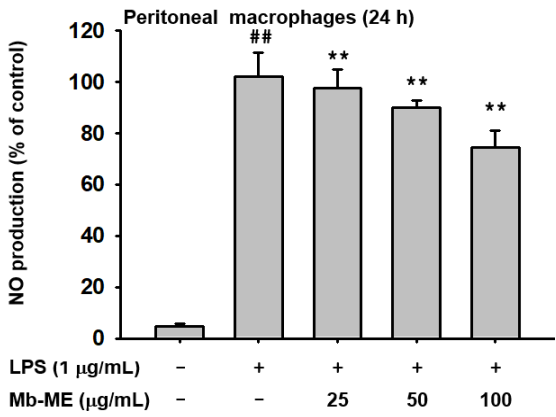

(B)

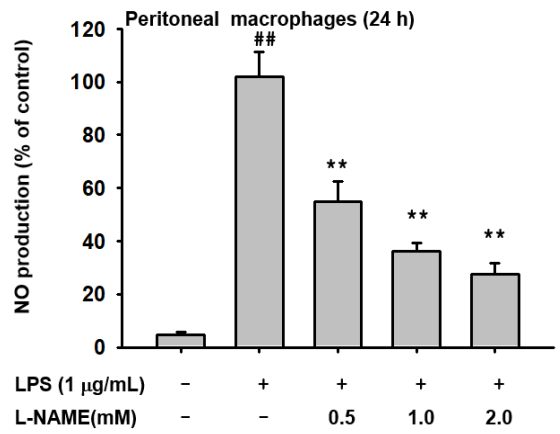

(D)

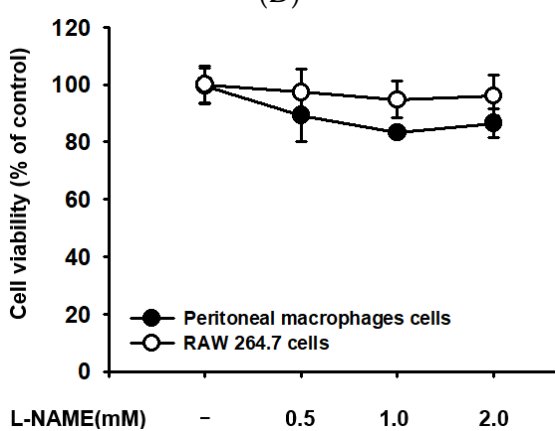

(F)

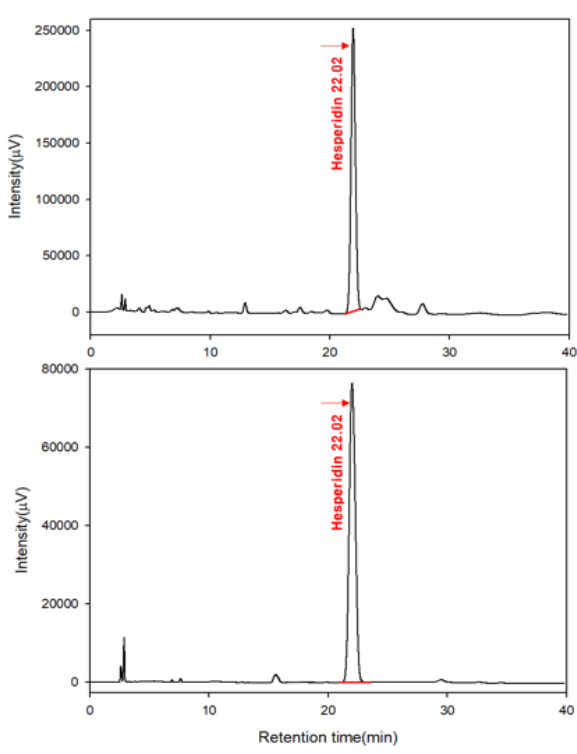

(H)

Figure 1. Effects of Mb-ME on the production of nitric oxide, cell viability, and HPLC. (A-D) Cells 
were pre-incubated with Mb-ME or L-NAME for $30 \mathrm{~min}$ and induced by LPS for $24 \mathrm{~h}$. Nitric oxide production was determined. (E,F) The cytotoxicity of Mb-ME and L-NAME was investigated. $(\mathbf{G}, \mathbf{H})$ A phytochemical fingerprinting profile of Mb-ME was obtained by HPLC analysis. The lower panels in $(\mathbf{G}, \mathbf{H})$ are the HPLC profiles of standard compounds quercetin and hesperidin that appeared in 6.05 and $22.02 \mathrm{~min}$, respectively. One millimole of L-NAME is $233.23 \mu \mathrm{g} / \mathrm{mL}$. ${ }^{\# \#} p<0.01$ and ** $p<0.01$ compared with the normal or control group.

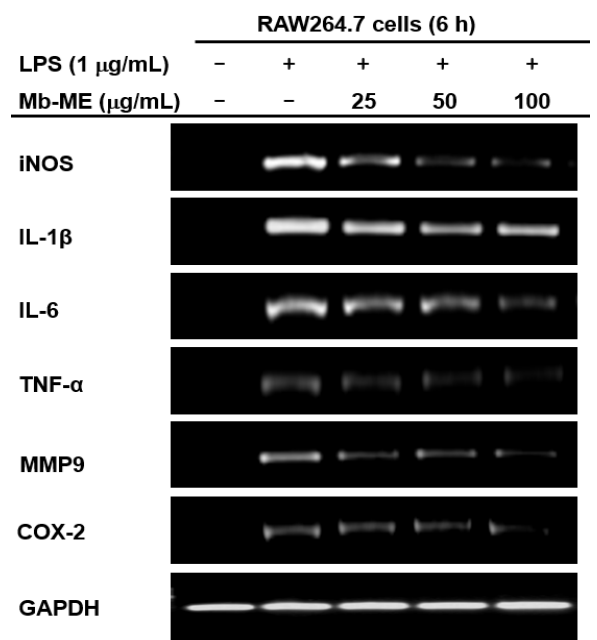

(A)

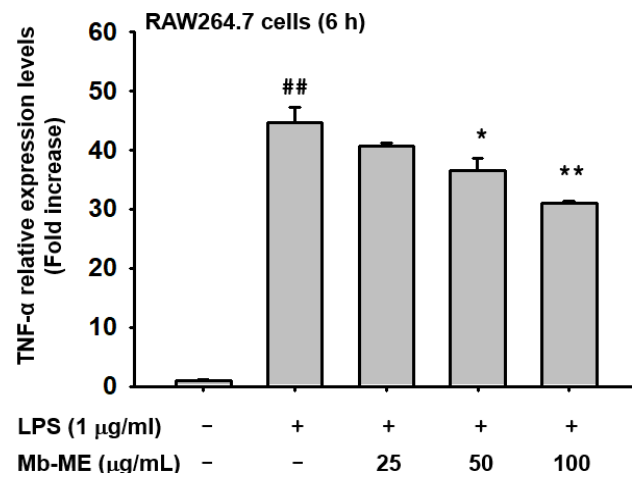

(C)

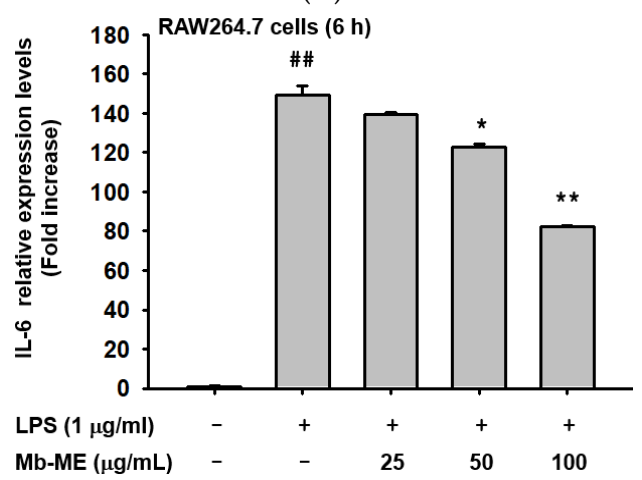

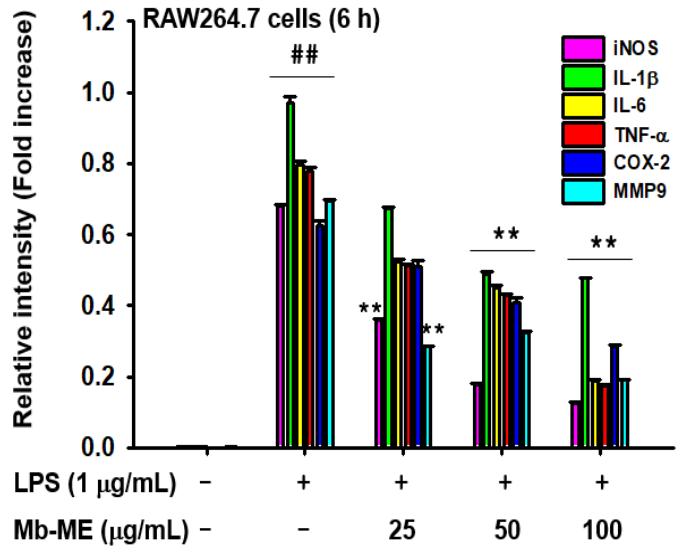

(B)

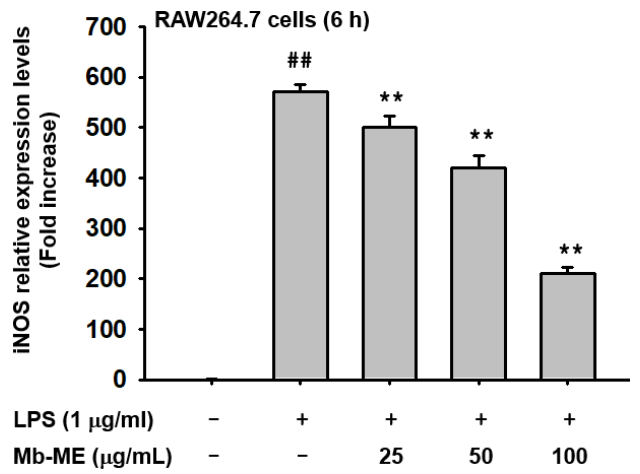

(D)

(E)

Figure 2. Inhibitory effects of Mb-ME on the expression of inflammatory genes. (A) RAW264.7 cells were pre-treated with Mb-ME for $30 \mathrm{~min}$ and incubated with LPS for $24 \mathrm{~h}$. The expression levels of inflammatory genes were assessed by an RT-PCR. (B) The relative intensity of (A) was measured by ImageJ. (C-E) The expression levels of TNF- $\alpha$, iNOS, and IL- 6 were detected by a quantitative PCR. \#\# $p<0.01$ compared with the normal group; ${ }^{*} p<0.05$ and ${ }^{* *} p<0.01$ compared with the normal or control group. 


\subsection{Effect of $M b-M E$ on the Translocation of Transcription Factors}

Luciferase activities were measured using HEK293 cells to identify whether the inhibition of inflammation-related genes was regulated by Mb-ME through the NF- $\mathrm{kB}$ signaling pathway. NF-KB-mediated luciferase activity was dramatically triggered by MyD88 and inhibited by Mb-ME in a dose-dependent manner (Figure 3A). Meanwhile, Mb-ME significantly $(p=0.004589)$ altered TRIF-stimulated luciferase activity at $100 \mu \mathrm{g} / \mathrm{mL}$ but not at $50 \mu \mathrm{g} / \mathrm{mL}$ (Figure 3B), suggesting that the influence of Mb-ME on MyD88-mediated NF- $\mathrm{kB}$ signaling pathways is stronger than its influence on TRIF-mediated NF- $\mathrm{kB}$ activity. To further ascertain if $\mathrm{Mb}-\mathrm{ME}$ did control NF- $\mathrm{KB}$ activation, the expression of p50 and $\mathrm{p} 65$, the most common heterodimers in the NF- $\mathrm{kB}$ signaling pathway, was evaluated at the protein level. Results showed that Mb-ME could largely attenuate both p50 and p65 at 15,30 , and $60 \mathrm{~min}$, indicating that Mb-ME affected the NF- KB activating activity (Figure 3C,D).

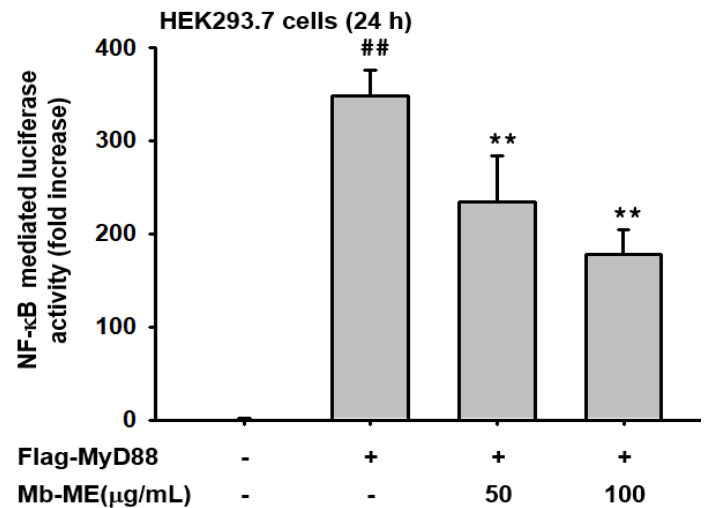

(A)

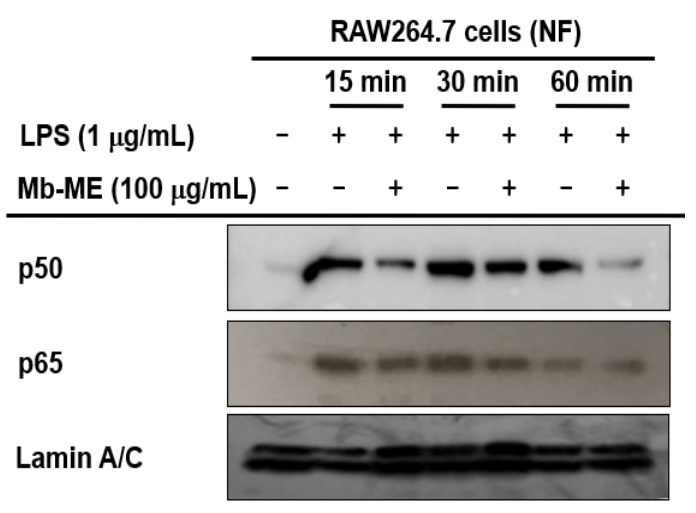

(C)

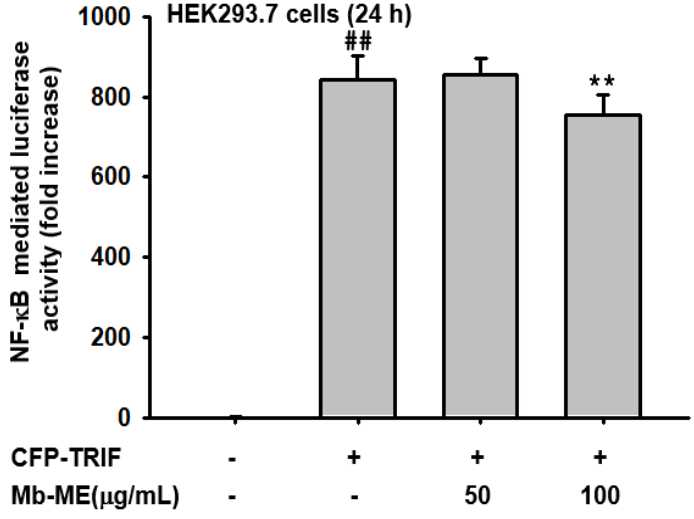

(B)

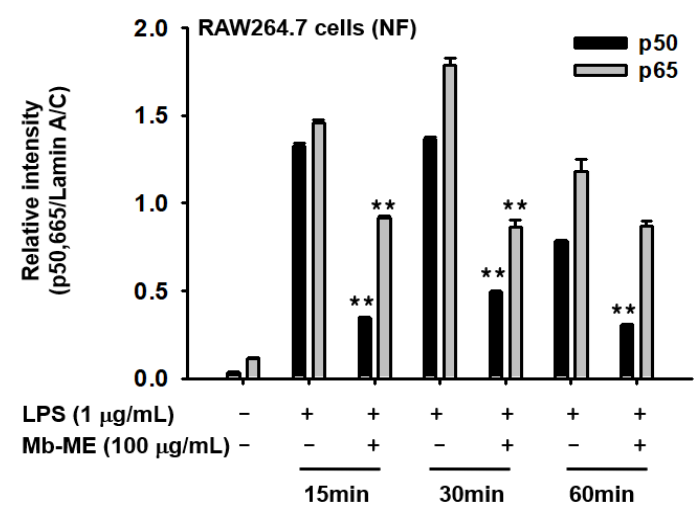

(D)

Figure 3. The anti-inflammatory effect of $\mathrm{Mb}-\mathrm{ME}$ on the transcription level of the NF- $\mathrm{kB}$ signaling pathway. (A,B) HEK293 cells were transfected with NF-kB-Luc, MyD88, TRIF, and $\beta$-gal for $24 \mathrm{~h}$ before Mb-ME treatment. (C) The effects of Mb-ME on nuclear protein levels of p50, p65, and Lamin A/C were examined by immunoblotting. (D) The relative intensity of p50 and p65 (C) was measured by ImageJ. ${ }^{\# \#} p<0.01$ compared with the normal group and ${ }^{* *} p<0.01$ compared with the control group.

\subsection{Effect of Mb-ME in Activating the NF- $\mathrm{B} B$ Upstream Signaling Pathway}

To confirm whether Mb-ME also modulates the upstream molecules of the NF- $\mathrm{kB}$ signaling cascade, the expression of intracellular proteins in both total- and phosphor-forms was examined at different LPS-treatment time points in the presence or absence of Mb-ME. Phosphorylated Akt (S473) was diminished by Mb-ME after LPS induction compared with non-Mb-ME-treated groups at all time points (Figure 4A,B). Nevertheless, Mb-ME blocked the phosphorylation of $\operatorname{I\kappa B} \alpha$ only at $5 \mathrm{~min}$. For the phosphorylation of $\operatorname{IKK} \alpha / \beta$, 
there was a clear inhibitory effect caused by $\mathrm{Mb}-\mathrm{ME}$ except at $15 \mathrm{~min}$. Since Mb-ME exerted inhibitory effects on Akt (S473) and I $\mathrm{B} \alpha$ induced by LPS at $5 \mathrm{~min}$, some earlier time points were assessed to further evaluate the upstream molecules. The blocking trend appeared after $\mathrm{Mb}-\mathrm{ME}$ treatment at almost all time points, especially the phosphorylation of IкB $\alpha$ and p85 (Figure 4B). Syk and Src are essential kinases for the initiation of signaling and could be activated to regulate various activities. Therefore, the phosphorylation of Syk and Src was investigated. As Figure 4B shows, Mb-ME offered a significant inhibitory effect on phosphorylation of Src at all time points, while the pattern of Syk could be observed only at 2 and $3 \mathrm{~min}$ after treating with LPS. To further determine the putative target protein of Mb-ME, an overexpression assay of Syk and Src was conducted. In Figure 4C,D, both Syk and Src overexpression increased the levels of phosphorylated forms of p85, Syk, and Src, whereas these events were significantly suppressed by Mb-ME treatment. To verify the inhibitory effect of Mb-ME on Src and Syk, immunoprecipitation was performed to evaluate the binding activity between Src and Syk and their substrates. As seen in Figure 4E,F, complex formation of p85 with either Src or Syk was abolished by Mb-ME, strongly implying Src and Syk as direct targets of Mb-ME.
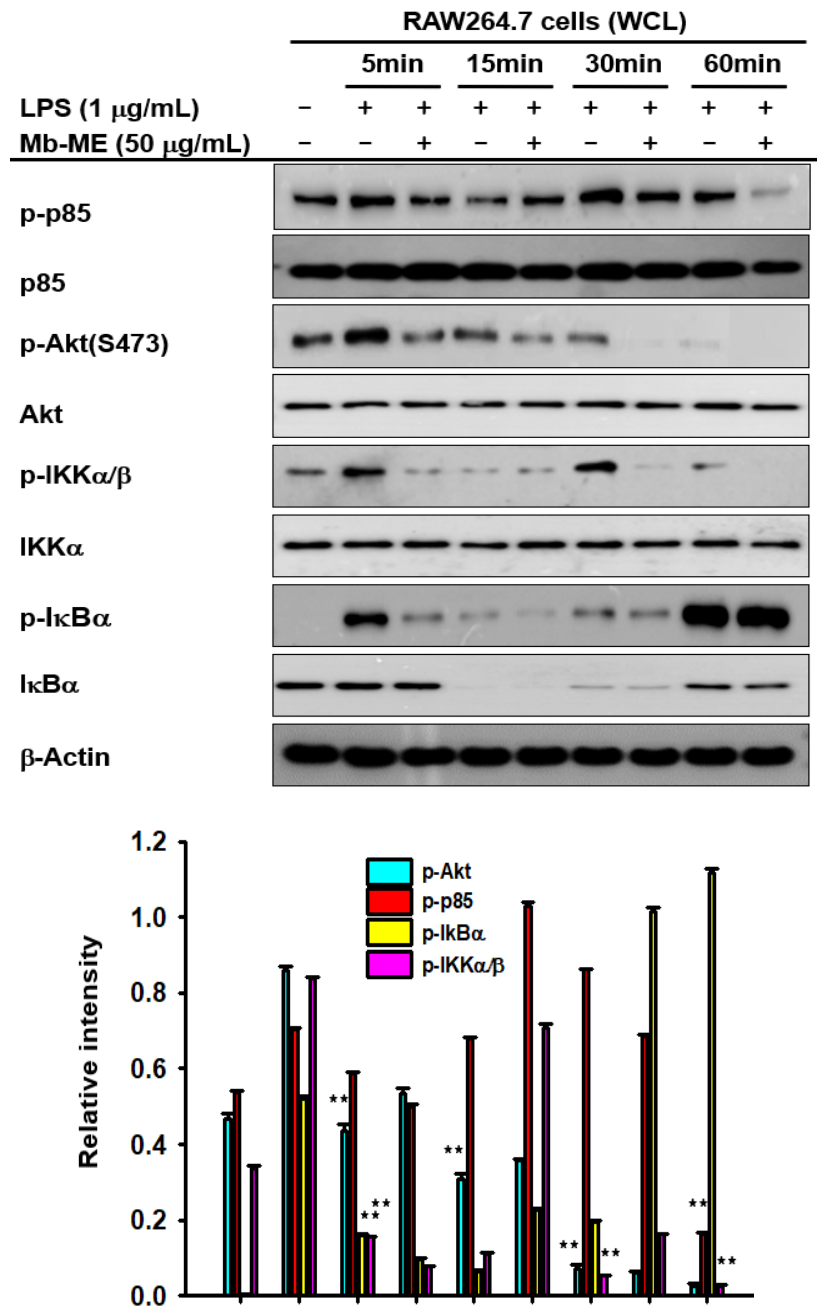

(A)

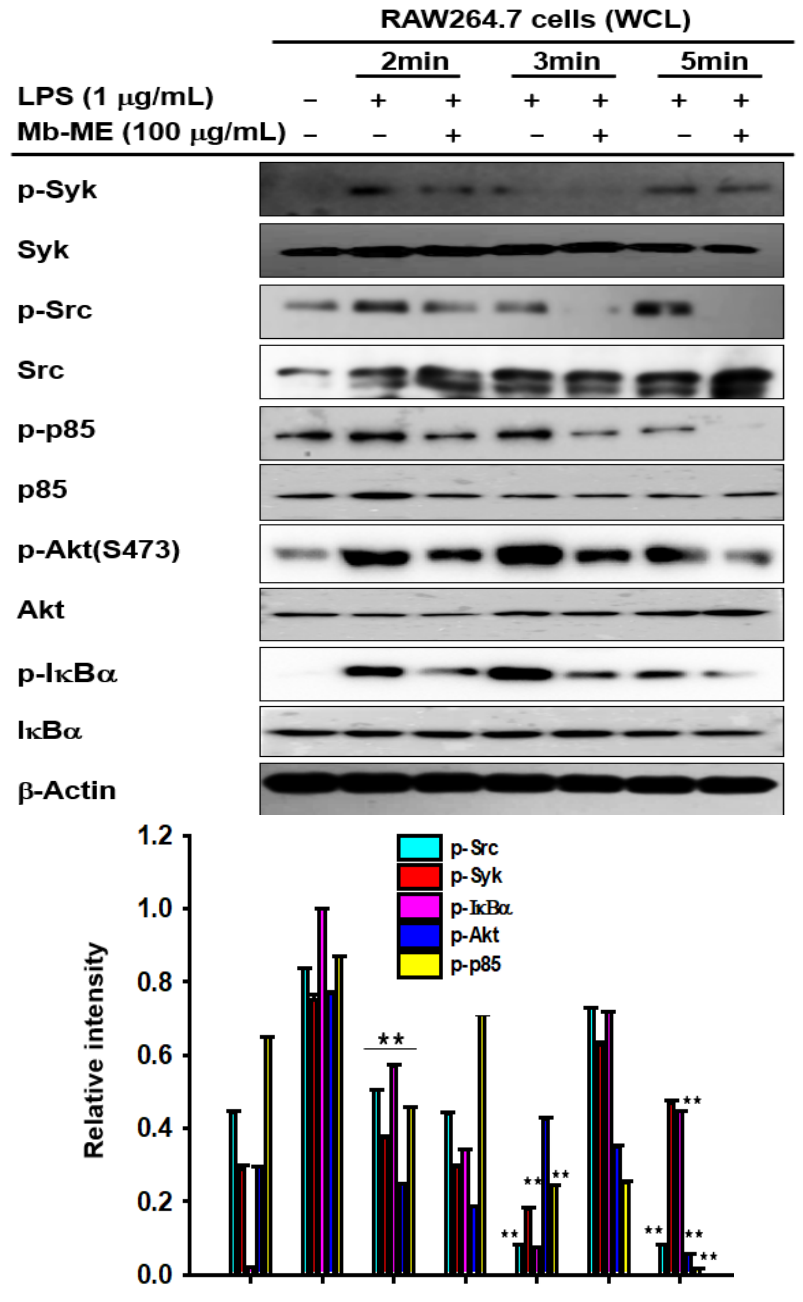

(B)

Figure 4. Cont. 


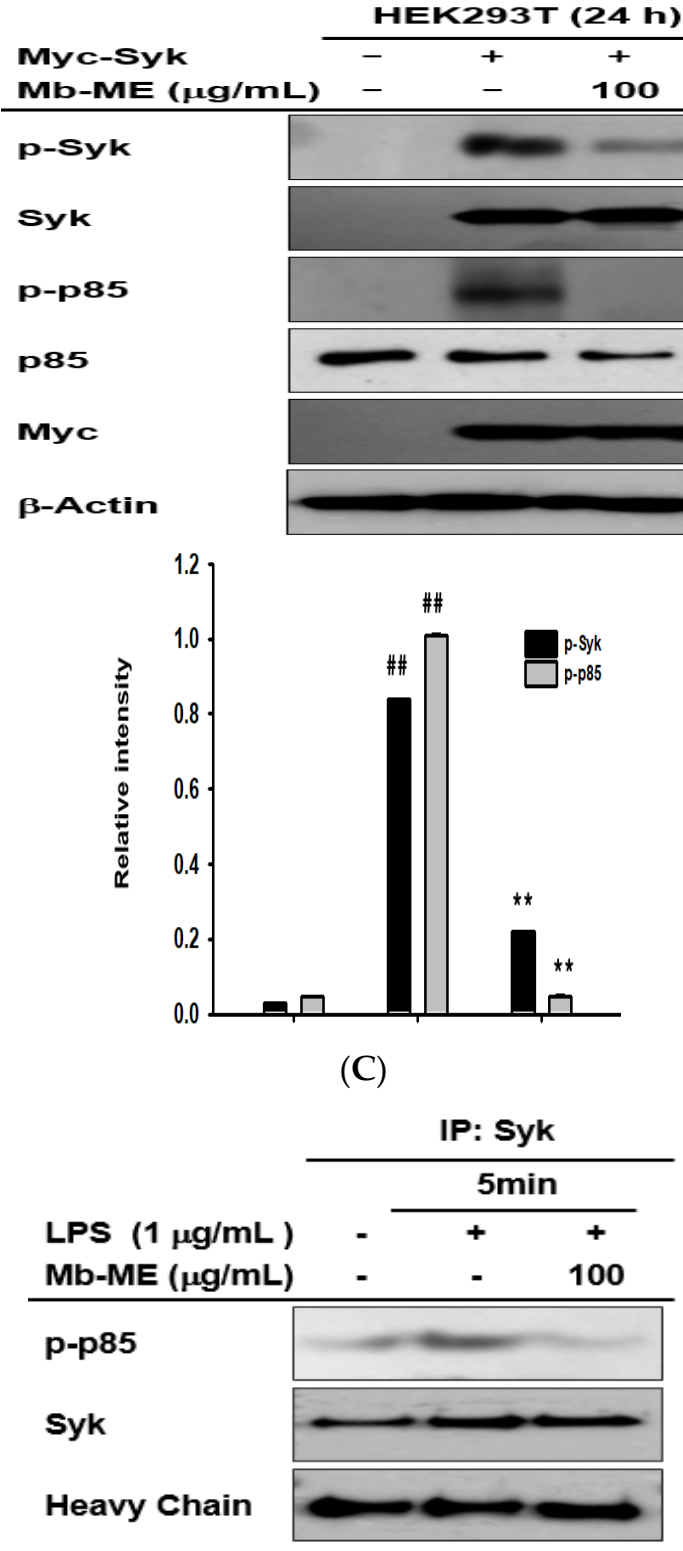

(E)

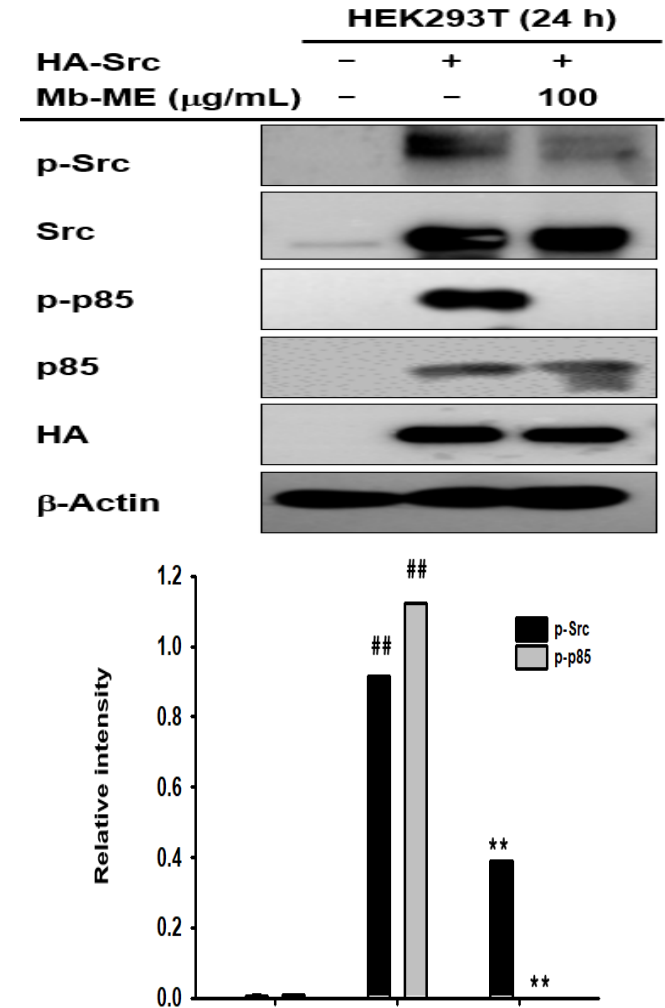

(D)

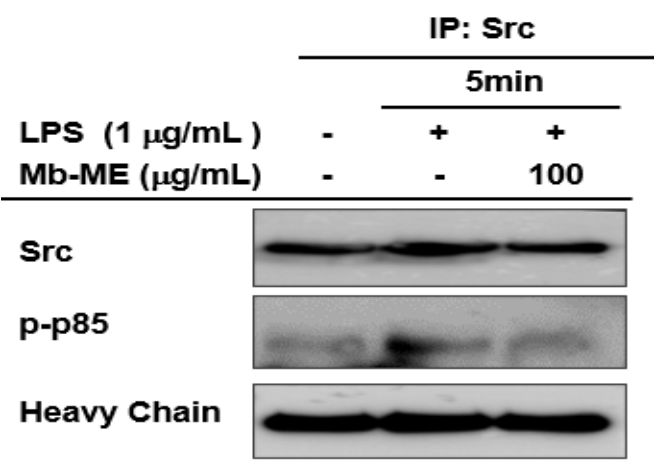

(F)

Figure 4. The regulatory effects of Mb-ME on NF- $k B$ signaling. (A,B) RAW264.7 cells were pretreated with $\mathrm{Mb}-\mathrm{ME}$, stimulated by LPS for specific time points. The phosphorylated and total forms of interested proteins were measured by Western blot analysis. (C) HEK293 cells overexpressing HA-Src or Myc-Syk were treated with Mb-ME for $24 \mathrm{~h}$. Phospho- and total forms of interested proteins were evaluated by immunoblotting. (D) RAW264.7 cells were induced with LPS in the presence or absence of $\mathrm{Mb}-\mathrm{ME}$ for $5 \mathrm{~min}$. (Lower panels in A-D) The relative intensity of signaling proteins (A,B) and Syk, Src or p85 (C,D) was measured by ImageJ. (E,F) The binding capacity of p-p85 to Src or Syk was examined by immunoprecipitation and immunoblotting analysis. ${ }^{\# \#} p<0.01$ compared to the normal group and ${ }^{* *} p<0.01$ compared with the control.

\subsection{Effect of $\mathrm{Mb}-\mathrm{ME}$ on In Vivo EtOH/HCl-Induced Gastritis}

To assess the therapeutic function of Mb-ME in inflammatory diseases in vivo, we used a gastritis mouse model triggered by $\mathrm{HCl} / \mathrm{EtOH}$. Ranitidine, which is used to treat and prevent ulcers in the stomach and intestines, was used as a positive control. Based on our previous study [22-25] and in vitro activity of Mb-ME showing a concentration range from 0 to $100 \mu \mathrm{g} / \mathrm{mL}$, we decided doses of $\mathrm{Mb}-\mathrm{ME}$ and ranitidine up to 200 and $40 \mathrm{mg} / \mathrm{kg}$, 
respectively. As shown in Figure 5A,B, Mb-ME strongly ameliorated the inflammatory lesion to a degree similar to that of ranitidine. The expression of COX-2 and TNF- $\alpha$ in stomach tissues was measured to confirm whether in vivo results were similar with in vitro data. As expected, the expression of both COX-2 and TNF- $\alpha$ exhibited a decreasing trend on Mb-ME treatment (Figure 5C). Moreover, the Western blotting results implied that $\mathrm{Mb}-\mathrm{ME}$ strongly diminishes the enhanced COX-2 level triggered by $\mathrm{HCl} / \mathrm{EtOH}$ in stomach lysates and the anti-gastritis ability of $\mathrm{Mb}-\mathrm{ME}$ was almost the same as that of ranitidine (Figure 5D). To confirm whether Mb-ME could also modulate the NF- $\mathrm{KB}$ in vivo condition, the expression of p-Syk and p-Src in stomach tissues was assessed. As expected, Mb-ME decreased the levels of both, especially the phosphorylated form of Syk (Figure 5D).

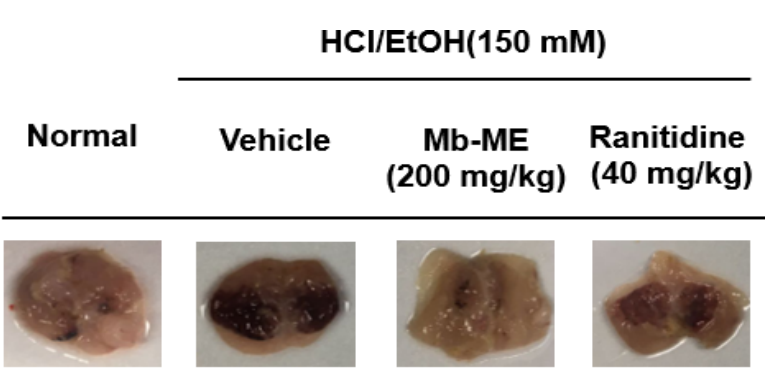

(A)

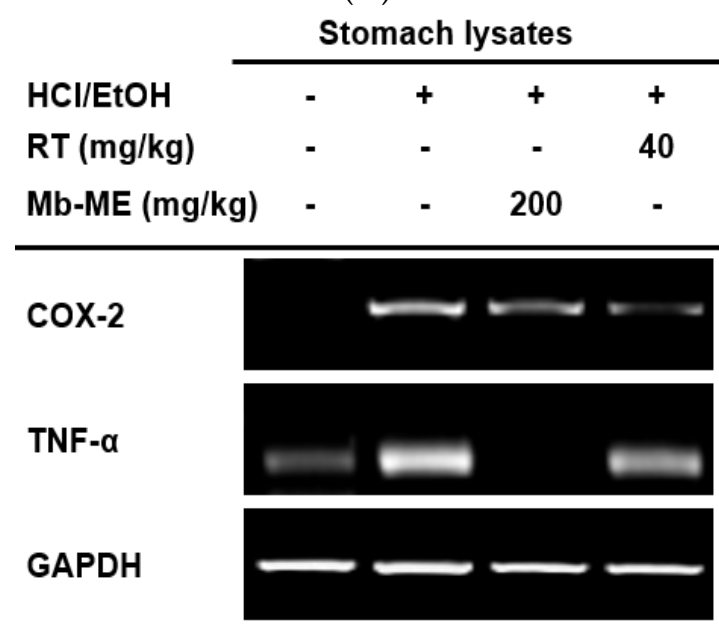

(C)

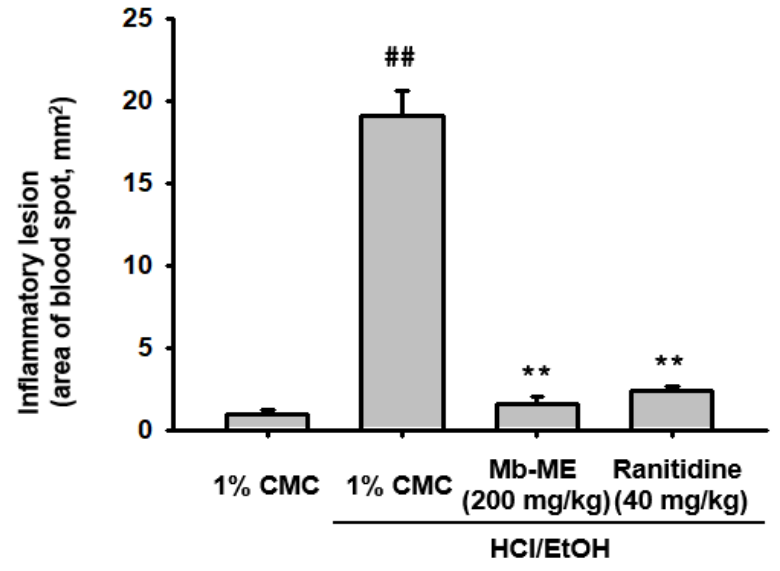

(B)

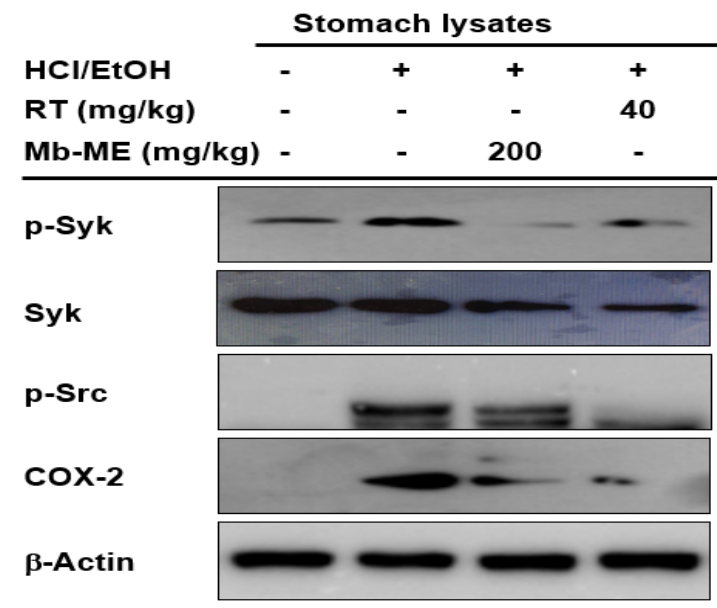

(D)

Figure 5. In vivo effect of $\mathrm{Mb}-\mathrm{ME}$ on $\mathrm{HCl} / \mathrm{EtOH}$-induced gastritis. (A,B) Mice were orally injected with $\mathrm{Mb}-\mathrm{ME}$ or ranitidine and gastritis was induced by $\mathrm{HCl} / \mathrm{EtOH}$. The mucosal erosive areas were calculated with ImageJ. (C,D) The mRNA and protein were isolated from stomach tissues. mRNA expression of COX-2 and TNF- $\alpha$ and protein levels of COX-2, p-Syk, Syk, and p-Src in gastritis stomach samples were evaluated by a PCR and immunoblotting, respectively. ${ }^{\#} p<0.01$ compared to the normal group and ${ }^{* *} p<0.01$ compared to the control.

\section{Discussion}

Malus baccata (L.) Borkh. is an important traditional medical plant. Several studies have revealed its anti-obesity, anti-oxidant, and immunomodulation activities, emphasizing its pharmacological importance [19]. However, the molecular mechanisms of this plant, including those of its leaves and shoots, in inflammatory responses remain poorly under- 
stood. The goal of this study was to reveal the molecular mechanism of Mb-ME-mediated anti-inflammatory activity using LPS-stimulated macrophages. Therefore, we investigated the anti-inflammatory effect of Mb-ME using RAW264.7 cells, as well as an acute gastritis murine model. Moreover, the target molecules of $\mathrm{Mb}-\mathrm{ME}$ were explored in the NF- $\mathrm{B}$ signaling pathways.

Nitric oxide is recognized as a mediator and regulator molecule that plays several roles in immunity and inflammation [26]. First, the production of nitric oxide was inhibited by Mb-ME without significant cytotoxicity upon LPS-induced RAW264.7 cells and primary peritoneal macrophages (Figure $1 \mathrm{~A}-\mathrm{F}$ ). As shown in Figure $1 \mathrm{G}, \mathrm{H}, \mathrm{Mb}-\mathrm{ME}$ contained quercetin and hesperidin, flavonoids famous for their anti-inflammatory and anti-oxidant effects. The effect of Mb-ME on Src and Syk phosphorylation and nitric oxide production might be attributed to these compounds. Further evidence is required to support this.

Inducible nitric oxide synthase (iNOS) is an enzyme that synthesizes nitric oxide [27]. Thus, the alteration of Mb-ME on mRNA expression of iNOS was investigated. As we expected, semi-quantitative and quantitative PCR results suggest that mRNA expression of iNOS is blocked by $\mathrm{Mb}-\mathrm{ME}$ in a dose-dependent manner. Mb-ME also suppressed other inflammatory genes, such as IL-6, MMP9, TNF- $\alpha$, IL-1 $\beta$, and COX-2 (Figure 2). In both innate and adaptive immune cells, NF- $\mathrm{kB}$ is a central mediator that mediates cell survival, differentiation, and activation of pro-inflammatory genes expression such as cytokines, chemokines, and coagulation factors [28]. Our results indicate that the nuclear translocation of p50 and p65, two subunits of NF-kB, was suppressed by Mb-ME. Moreover, Mb-ME simultaneously inhibited the luciferase activity of NF- $\mathrm{B}$ that was triggered by MyD88 and TRIF (Figure 3). Our experiment implies that Mb-ME plays a suppressive role in nitric oxide production and pro-inflammatory genes, accomplished by blocking the nuclear transcription and activity of NF- $\mathrm{kB}$.

The nuclear transcription of NF-kB involves the activation of $\mathrm{I} \kappa \mathrm{B} \alpha$ (inhibitors of NFкB), Akt, and IkB kinase (IKK) [29,30]. Moreover, phosphatidyl-inositol-3-kinase (PI3K), Syk, and Src are upstream molecules of the NF- $\kappa B$ signaling pathway. Mb-ME suppressed the phosphorylation of Akt, IKK $\alpha / \beta$, and I $\mathrm{B} B \alpha$ in LPS-stimulated macrophages at most of the tested time points (Figure $4 \mathrm{~A}$ ). A significant reduction in IкB $\alpha$ at 5 min was observed. In certain cytokine responses, it is believed that Src and Syk family kinases usually act downstream of the Toll-like receptors by interacting with Src and Syk at earlier time points. In agreement with our expectation, the phosphorylation of Src, Syk, and p85 was enhanced by LPS stimulation while it was downregulated by Mb-ME treatment at 2, 3, and $5 \mathrm{~min}$ (Figure 4B). Our hypothesis is that Mb-ME targeted Src and Syk. To verify this, overexpression of Src and Syk was employed. Consistent with Figure 4B, the phosphorylation of Src and Syk and their downstream enzyme, p85, was inhibited by Mb-ME, which implied Src and Syk as direct targets during Mb-ME-mediated anti-inflammatory activities (Figure 4C,D). Molecular complex formation between Src/Syk and PI3K was blocked by Mb-ME (Figure 4E,F). Moreover, an in vivo experiment confirmed that the oral administration of $\mathrm{Mb}-\mathrm{ME}$ ameliorated $\mathrm{HCl} / \mathrm{EtOH}$-induced acute gastritis (Figure 5). In general, the anti-inflammatory activity of $\mathrm{Mb}-\mathrm{ME}$ is driven by the suppression of $\mathrm{p}-\mathrm{Syk}$ and $\mathrm{p}-\mathrm{Src}$ in NF-kB pathways.

\section{Materials and Methods}

\subsection{Materials}

The methanol extract of Malus baccata (L.) Borkh (Mb-ME) was obtained from the Plant Extract Bank in the Plant Diversity Research Center (Daejeon, Korea). The RAW264.7 (murine macrophages) cells and HEK293 (human embryonic kidney) cells were purchased from ATCC (Rockville, MD, USA). The reagents used for culturing cells were purchased from Gibco (Grand Island, NY, USA). Lipopolysaccharide (LPS), polyethylenimine (PEI), ranitidine, sodium carboxymethyl cellulose (Na-CMC), and other chemicals were obtained from Sigma Chemical Co. (St. Louis, MO, USA). Phospho-specific and total antibodies 
recognizing $\beta$-actin, IKB $\alpha, \mathrm{p} 50, \mathrm{IKK} \alpha / \beta, \mathrm{HA}$, Src, p65, Syk, p85, Lamin A/C, Akt, p85, I $\kappa \alpha$, and Myc were purchased from Cell Signaling (Beverly, MA, USA).

\subsection{Plant Information and Extraction Methods}

Malus baccata (L.) Borkh. was collected from Xiao Longman National Forest Park, Mentougou district, Beijing, China, and identified by Dr. Zhiyun Zhang at the Institute of Botany in May 2012. A voucher specimen (accession number KRIB 0041120) of the retained material is preserved at the herbarium of KRIBB. The leaves and shoots of Malus baccata $(19 \mathrm{~g})$ were extracted with $1 \mathrm{~L}$ of $99.9 \%(\mathrm{v} / \mathrm{v})$ methanol under repeated sonication (15 min) and rest $(2 \mathrm{~h})$ for 3 days at $45^{\circ} \mathrm{C}$. The resultant product was filtered with non-fluorescence cottons and concentrated by a rotary evaporator (N-1000SWD, EYELA) under reduced pressure at $45^{\circ} \mathrm{C}$. Finally, a total $4.09 \mathrm{~g}$ of methanol extract of Malus baccata was obtained by freeze-drying.

\subsection{Cell Culture}

RAW264.7 cells and HEK293 cells were cultured in RPMI1640 supplemented with $10 \%$ fetal bovine serum or DMEM supplemented with $5 \%$ fetal bovine serum, respectively. Cells were incubated in $5 \% \mathrm{CO}_{2}$ at $37^{\circ} \mathrm{C}$ and passaged two times a week.

\subsection{Drug Preparation}

A stock solution $(100 \mathrm{mg} / \mathrm{mL})$ of Mb-ME solved with $100 \%$ DMSO was first diluted with DMSO to have various concentrations of $\mathrm{Mb}-\mathrm{ME}(25,50$, and $100 \mathrm{mg} / \mathrm{mL})$. For preparing in vitro working concentrations $(25,50$, and $100 \mu \mathrm{g} / \mathrm{mL})$ of Mb-ME, a culture medium was used for the final dilution. Mb-ME was prepared in $1 \% \mathrm{Na}-\mathrm{CMC}$ for the in vivo experiment [31]. LPS (stock solution $1 \mathrm{mg} / \mathrm{mL}$ ) was also diluted with the culture medium to reach a working concentration $(1 \mu \mathrm{g} / \mathrm{mL})$.

\subsection{Animals}

ICR mice and C57BL/ 6 mice were obtained from Dae Han Bio Link (Osong, Korea) [32]. Food pellets and water were supplied ad libitum [33]. All studies were performed in accordance with guidelines established by the Sungkyunkwan University Institutional Animal Care and Use Committee.

\subsection{Preparation of Peritoneal Macrophages}

To obtain peritoneal macrophages, sterile thioglycollate broth was intraperitoneally injected into male C57BL/ 6 mice and lavaged for 4 days [34]. The exudates were washed with an RPMI medium containing 10\% FBS [35]. Peritoneal macrophages were plated in $100 \mathrm{~mm}$ tissue culture dishes.

\subsection{Nitric Oxide Production Assay}

RAW264.7 cells and peritoneal macrophages were seeded into 96-well plates. The cells were pre-treated with $\mathrm{Mb}$-ME for $30 \mathrm{~min}$ and induced with LPS for $24 \mathrm{~h}$, and $100 \mu \mathrm{L}$ of the supernatant was transferred to a new 96-well plate and mixed with Griess reagent. The nitric oxide production level was calculated by measuring absorbance at $540 \mathrm{~nm}$ [36].

\subsection{Cell Viability Assay}

The cells were treated with the indicated concentration of Mb-ME or L-NAME for $24 \mathrm{~h}$ [37]. Then, $10 \mu \mathrm{L}$ of MTT solution was distributed to each well. The reaction was terminated by adding $100 \mu \mathrm{L}$ of MTT stopping solution. The cytotoxicity of Mb-ME and L-NAME was explored by determining the absorbance at $570 \mathrm{~nm}$.

\subsection{High-Performance Liquid Chromatography (HPLC)}

HPLC was performed with the Jasco HPLC system including a UV-Vis detector to identify the bioactive components of Mb-ME [15,38]. The injection volume was $10 \mu \mathrm{L}$, 
and the flow rate was $1.0 \mu \mathrm{L} / \mathrm{min}$. Quercetin and hesperidin were employed as the standard compounds [39]. The HPLC conditions for analyzing quercetin and hesperidin in $\mathrm{Mb}-\mathrm{ME}$ are explained in Table 1.

Table 1. HPLC conditions.

\begin{tabular}{ccc}
\hline Analyzing Compound & Quercetin & Hesperidin \\
\hline Column & $\begin{array}{c}\text { CAPCELL PAK C18 MG, } \\
4.6 \mathrm{~mm} \text { I.D. } \times 250 \mathrm{~mm}\end{array}$ & $\begin{array}{c}\text { CAPCELL PAK C18 MG, } \\
4.6 \mathrm{~mm} \text { I.D. } \times 250 \mathrm{~mm}\end{array}$ \\
\hline Wavelength $(\mathrm{nm})$ & 254 & 285 \\
\hline Mobile phase & A: $2 \%$ acetic acid in water & B: $0.5 \%$ acetic acid in water: \\
CAN $=50: 50$ & $\begin{array}{c}\text { Methanol: water of acetic acid } \\
(\mathrm{pH} 3)=30: 70\end{array}$ \\
Gradient or isocratic & 0: A (28\%), B (72\%) & 40 min: $100 \%$ \\
conditions & 20 min: B $(100 \%)$ & 50 \\
\hline Oven temperature $\left({ }^{\circ} \mathrm{C}\right)$ & 30 min: B $(100 \%)$ & \\
\hline
\end{tabular}

\subsection{Plasmid Transfection and Luciferase Reporter Assay}

HEK293 cells were transfected with Syk, Src, MyD88, TRIF, or NF-kB Luc via PEI for $24 \mathrm{~h}$ [40]. The above cells were further treated with Mb-ME for $24 \mathrm{~h} \mathrm{[41].} \mathrm{A} \mathrm{luciferase} \mathrm{assay}$ was performed to test the effect of Mb-ME on NF- $\mathrm{BB}$ activity. Cells overexpressing Syk or Src were further incubated with $\mathrm{Mb}-\mathrm{ME}$ for $24 \mathrm{~h}$, harvested, and subjected to immunoblotting.

\subsection{1. mRNA Analysis by a Reverse Transcription Polymerase Chain Reaction}

Following pretreatment by Mb-ME for $30 \mathrm{~min}$, RAW264.7 cells were induced with LPS for $6 \mathrm{~h}$. Total RNA was isolated using TRIzol reagent. Complementary DNA was synthesized using mRNA as the template. A reverse transcription polymerase chain reaction (RT-PCR) and a real-time PCR were performed [42]. All the primers are listed in Tables 2 and 3 .

Table 2. Sequences of mouse primers used in the semi-quantitative RT-PCR.

\begin{tabular}{|c|c|c|}
\hline Name & Primer & Sequence $\left(5^{\prime}\right.$ to $\left.3^{\prime}\right)$ \\
\hline \multirow{2}{*}{ iNOS } & Forward & GTGAAGAAAACCCCTTGTGCTG \\
\hline & Reverse & AGTTCCGAGCGTCAAAGACC \\
\hline \multirow{2}{*}{ IL-1 $\beta$} & Forward & CAGGATGAGGACATGAGCACC \\
\hline & Reverse & CTCTGCAGACTCAAACTCCAC \\
\hline \multirow{2}{*}{ IL-6 } & Forward & GCCTTCTTGGGACTGATGCT \\
\hline & Reverse & TGGAAATTGGGGTAGGAAGGAC \\
\hline \multirow{2}{*}{$\mathrm{TNF}-\alpha$} & Forward & TTGACCTCAGCCGTGAGTTG \\
\hline & Reverse & CCTGTAGCCCACGTCGTAGC \\
\hline \multirow{2}{*}{ MMP-9 } & Forward & TCTTCCCCAAAGACCTGAAA \\
\hline & Reverse & TGATGTTATGATGGTCCCAC \\
\hline \multirow{2}{*}{ COX-2 } & Forward & CACTACATCCTGACCCACTT \\
\hline & Reverse & ATGCTCCTGCTTGAGTATGT \\
\hline \multirow{2}{*}{ GADPH } & Forward & ACCACAGTCCATGCCATCAC \\
\hline & Reverse & CCACCACCCTGTTGCTGTAG \\
\hline
\end{tabular}

\subsection{Preparation of Total Cell and Nuclear Lysates}

Experimental RAW264.7 cells and HEK293 cells were harvested and resuspended in lysis buffer. For nuclear fractionation, RAW264.7 cells were harvested and resuspended in 
nuclear protein extraction buffer [43]. The nuclear extract and whole protein lysates were isolated by centrifugation and stored at $-80{ }^{\circ} \mathrm{C}$.

Table 3. Sequences of mouse primers used in the real-time PCR.

\begin{tabular}{|c|c|c|}
\hline Name & Primer & Sequence $\left(5^{\prime}\right.$ to $\left.3^{\prime}\right)$ \\
\hline \multirow{2}{*}{$\mathrm{TNF}-\alpha$} & Forward & TGCCTATGTCTCAGCCTCTT \\
\hline & Reverse & GAGGCCATTTGGGAACTTCT \\
\hline \multirow{2}{*}{ iNOS } & Forward & CGAAACGCTTCACTTCCAA \\
\hline & Reverse & TGAGCCTATATTGCTGTGGCT \\
\hline \multirow{2}{*}{ IL-6 } & Forward & GTCCTTCCTACCCCAATTTCCA \\
\hline & Reverse & TAACGCACTAGGTTTGCCGA \\
\hline \multirow{2}{*}{ GADPH } & Forward & GGGTCCCAGCTTAGGTTCATC \\
\hline & Reverse & TACGGCCAAATCCGTTCACA \\
\hline
\end{tabular}

\subsection{Immunoblotting}

A Bradford assay was employed to determine the protein concentration of samples. The proteins of whole cells or nuclear lysates were then subjected to immunoblotting, as performed previously [44]. The phosphorylated or total proteins of p85, Akt, IKK $\alpha / \beta$, Syk, Src, Myc, HA, COX-2, and $\beta$-actin were visualized using an ECL system [45].

\subsection{Immunoprecipitation}

Proteins was isolated from RAW264.7 cells treated with Mb-ME and LPS. Lysates containing equal amounts of proteins were incubated with $3 \mu \mathrm{L}$ Syk- or Src-specific antibodies at $4{ }^{\circ} \mathrm{C}$ overnight. The protein complexes were mixed with $10 \mu \mathrm{L}$ of protein A-conjugated agarose beads for $4 \mathrm{~h}$ at $4{ }^{\circ} \mathrm{C}$ [46]. Protein complexes were washed, and the beads were boiled. The proteins were isolated and then subjected to immunoblotting.

\subsection{5. $\mathrm{HCl} / \mathrm{EtOH}$-Induced Gastritis}

The acute gastritis model was induced with $\mathrm{EtOH} / \mathrm{HCl}$ in $25 \mathrm{ICR}$ mice. Fasted mice (6 mice/group) were orally administered $\mathrm{Mb}-\mathrm{ME}$ or ranitidine twice per day for 2 days [31]. One hour after the final oral administration, the mice were orally injected with $400 \mu \mathrm{L}$ of $60 \%$ ethanol in $150 \mathrm{mM} \mathrm{HCl}$ [47]. The mice were anesthetized and sacrificed after 1 h. The mRNA and protein were isolated from stomach tissue lysates for an RT-PCR and immunoblotting analysis, respectively.

\subsection{Statistical Analysis}

Data are expressed as the mean \pm the standard deviation of experiments performed with triplicate samples for the in vitro experiments or with septuplicate samples for the in vivo experiments. SPSS (Ver. 22) was employed to evaluate the differences between groups. $p<0.05$ was considered statistically significant.

\section{Conclusions}

In summary, in this study, Mb-ME reduced the production of nitric oxide; decreased the mRNA expression of pro-inflammatory genes such as TNF- $\alpha$, IL-6, and iNOS; and relieved acute gastritis symptoms triggered by $\mathrm{HCl} / \mathrm{EtOH}$ treatment. This extract also showed the suppression of Src and Syk activities, leading to a reduction of the NF- $\mathrm{KB}$ activation pathway under LPS-activated conditions, as summarized in Figure 6. Our results imply that $\mathrm{Mb}-\mathrm{ME}$ provides an anti-inflammatory effect by targeting the NF- $\mathrm{kB}$ signaling pathway both in vivo and in vitro. The potential anti-inflammatory function suggests $\mathrm{Mb}-\mathrm{ME}$ as an ideal therapeutic candidate in inflammatory illness. Therefore, we will continue a more detailed pre-clinical study against various gastritis diseases with the ethanol or water extracts of this plant. 


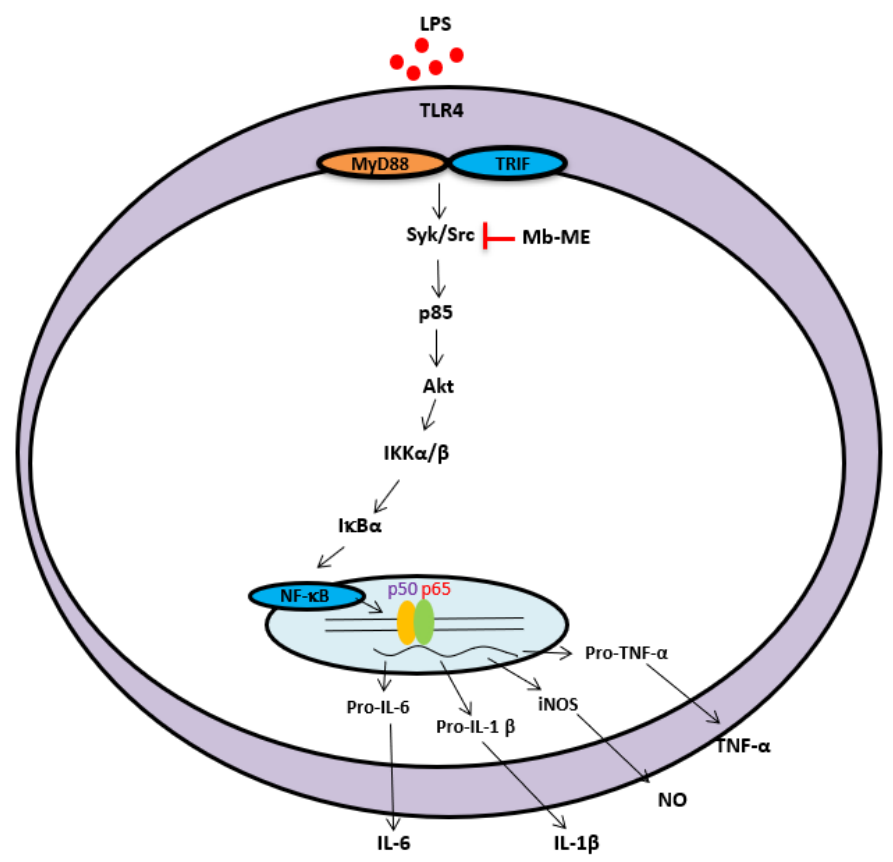

Figure 6. The potential inhibitory pathway of Mb-ME-mediated anti-inflammatory activities.

Author Contributions: C.S., J.-H.K., and J.Y.C. conceived and designed the experiments; C.S., J.H.K., and J.Y.C. analyzed the data; C.S., H.C., S.A.K., J.S.L., E.S.C., Z.Z., and S.-Y.K. performed the experiments; C.S., J.-H.K., and J.Y.C. wrote the manuscript. All authors have read and agreed to the published version of the manuscript.

Funding: This research was supported by the Basic Science Research Program through the National Research Foundation of Korea, funded by the Ministry of Education (2017R1A6A1A03015642), Korea, and the APC was funded by KRF.

Institutional Review Board Statement: Not applicable.

Informed Consent Statement: Not applicable.

Data Availability Statement: The data are contained within the article.

Conflicts of Interest: The authors have no conflicts of interest to declare. DanjoungBio Co., Ltd has no conflicts of interest with the paper.

$\begin{array}{ll}\text { Abbreviations } \\ \text { AP-1 } & \text { Activator protein } 1 \\ \text { COX-2 } & \text { Cyclooxygenease-2 } \\ \text { HPLC } & \text { High-performance liquid chromatography } \\ \text { iNOS } & \text { Inducible nitric oxide synthase } \\ \text { IL-1 } \beta & \text { Interleukin } 1 \beta \\ \text { IL-6 } & \text { Interleukin } 6 \\ \text { JAK-STAT } & \text { Janus kinase-signal transducer and activator of transcription } \\ \text { LPS } & \text { Lipopolysaccharides } \\ \text { Mb-ME } & \text { Malus baccata methanol extract } \\ \text { MyD88 } & \text { Myeloid differentiation primary response } 88 \\ \text { MMP9 } & \text { Matrix metallopeptidase } 9 \\ \text { NF-kB } & \text { Nuclear factor-kB } \\ \text { Na-CMC } & \text { Sodium carboxymethyl cellulose } \\ \text { PRR } & \text { Pattern recognition receptor } \\ \text { pp85 } & \text { Phospho-PI3 kinase p85 } \\ \text { RT-PCR } & \text { Reverse transcription polymerase chain reaction } \\ \text { SrC } & \text { Non-receptor tyrosine kinase }\end{array}$




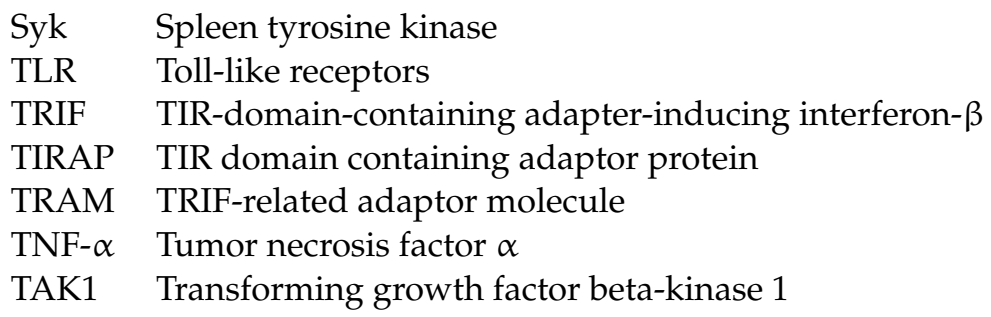

\section{References}

1. Chang, Y.L.; Liao, Y.W.; Chen, M.H.; Chang, S.Y.; Huang, Y.T.; Ho, B.C.; Yu, S.L. IKKe isoform switching governs the immune response against EV71 infection. Commun. Biol. 2021, 4, 663. [CrossRef] [PubMed]

2. Garibotto, G.; Carta, A.; Picciotto, D.; Viazzi, F.; Verzola, D. Toll-like receptor-4 signaling mediates inflammation and tissue injury in diabetic nephropathy. J. Nephrol. 2017, 30, 719-727. [CrossRef] [PubMed]

3. Yu, H.; Bruneau, R.C.; Brennan, G.; Rothenburg, S. Battle Royale: Innate recognition of poxviruses and viral immune evasion Biomedicines 2021, 9, 765. [CrossRef] [PubMed]

4. Roy, A.; Srivastava, M.; Saqib, U.; Liu, D.; Faisal, S.M.; Sugathan, S.; Bishnoi, S.; Baig, M.S. Potential therapeutic targets for inflammation in toll-like receptor 4 (TLR4)-mediated signaling pathways. Int. Immunopharmacol. 2016, 40, 79-89. [CrossRef] [PubMed]

5. O'Neill, L.A.J.; Bowie, A.G. The family of five: TIR-domain-containing adaptors in Toll-like receptor signalling. Nat. Rev. Immunol. 2007, 7, 353-364. [CrossRef] [PubMed]

6. Jung, Y.J.; Jung, J.I.; Cho, H.J.; Choi, M.-S.; Sung, M.-K.; Yu, R.; Kang, Y.-H.; Park, J.H.Y. Berteroin present in cruciferous vegetables exerts potent anti-inflammatory properties in murine macrophages and mouse skin. Int. J. Mol. Sci. 2014, 15, 20686-20705. [CrossRef]

7. Chen, L.; Deng, H.; Cui, H.; Fang, J.; Zuo, Z.; Deng, J.; Li, Y.; Wang, X.; Zhao, L. Inflammatory responses and inflammationassociated diseases in organs. Oncotarget 2018, 9, 7204. [CrossRef]

8. Yeung, Y.T.; Aziz, F.; Guerrero-Castilla, A.; Arguelles, S. Signaling pathways in inflammation and anti-inflammatory therapies. Curr. Pharm. Des. 2018, 24, 1449-1484. [CrossRef]

9. Hemmati, S.; Haque, T.; Gritsman, K. Inflammatory signaling pathways in preleukemic and leukemic stem cells. Front. Oncol. 2017, 7, 265. [CrossRef]

10. Wang, N.; Liang, H.; Zen, K. Molecular mechanisms that influence the macrophage M1-M2 polarization balance. Front. Immunol. 2014, 5, 614. [CrossRef]

11. Ahuja, A.; Kim, J.H.; Kim, J.H.; Yi, Y.S.; Cho, J.Y. Functional role of ginseng-derived compounds in cancer. J. Ginseng Res. 2018, 42, 248-254. [CrossRef] [PubMed]

12. Kim, J.H.; Yi, Y.S.; Kim, M.Y.; Cho, J.Y. Role of ginsenosides, the main active components of Panax ginseng, in inflammatory responses and diseases. J. Ginseng Res. 2017, 41, 435-443. [CrossRef] [PubMed]

13. Xue, Q.; He, N.; Wang, Z.; Fu, X.; Aung, L.H.H.; Liu, Y.; Li, M.; Cho, J.Y.; Yang, Y.; Yu, T. Functional roles and mechanisms of ginsenosides from Panax ginseng in atherosclerosis. J. Ginseng Res. 2021, 45, 22-31. [CrossRef] [PubMed]

14. Lorz, L.R.; Kim, M.Y.; Cho, J.Y. Medicinal potential of Panax ginseng and its ginsenosides in atopic dermatitis treatment. J. Ginseng Res. 2020, 44, 8-13. [CrossRef] [PubMed]

15. Dadwal, V.; Agrawal, H.; Sonkhla, K.; Joshi, R.; Gupta, M. Characterization of phenolics, amino acids, fatty acids and antioxidant activity in pulp and seeds of high altitude Himalayan crab apple fruits (Malus baccata). J. Food Sci. Technol. 2018, 55, 2160-2169. [CrossRef]

16. Sharma, R.; Nath, A.K. Antioxidant levels and activities of reactive oxygen-scavenging enzymes in crab apple fruits (Malus baccata). Proc. Natl. Acad. Sci. India Sect. B Biol. Sci. 2016, 86, 877-885. [CrossRef]

17. Mulabagal, V.; Van Nocker, S.; Dewitt, D.L.; Nair, M.G. Cultivars of apple fruits that are not marketed with potential for anthocyanin production. J. Agric. Food Chem. 2007, 55, 8165-8169. [CrossRef]

18. Wei, X.; Zhao, R.; Sun, Y.-H.; Cong, J.-P.; Meng, F.-G.; Zhou, H.-M. The leaf extract of Siberian Crabapple (Malus baccata (Linn.) Borkh) contains potential fatty acid synthase inhibitors. J. Enzym. Inhib. Med. Chem. 2009, 24, 234-240. [CrossRef]

19. Wang, L.; Li, X.; Wang, Z. Whole body radioprotective effect of phenolic extracts from the fruits of Malus baccata (Linn.) Borkh. Food Funct. 2016, 7, 975-981. [CrossRef]

20. Yoshizawa, Y.; Sakurai, K.; Kawaii, S.; Soejima, J.; Murofushi, N. Antiproliferative and antioxidant properties of crabapple juices. Food Sci. Technol. Res. 2004, 10, 278-281. [CrossRef]

21. Sharma, J.N.; Al-Omran, A.; Parvathy, S.S. Role of nitric oxide in inflammatory diseases. Inflammopharmacology 2007, 15, 252-259. [CrossRef] [PubMed]

22. Yang, Y.; Yang, W.S.; Yu, T.; Sung, G.-H.; Park, K.W.; Yoon, K.; Son, Y.-J.; Hwang, H.; Kwak, Y.-S.; Lee, C.-M.; et al. ATF2/CREB/IRF-3-targeted anti-inflammatory activity of Korean red ginseng water extract. J. Ethnopharmacol. 2014, 154, 218-228. [CrossRef] [PubMed] 
23. Kim, S.A.; Lee, C.Y.; Mitra, A.; Kim, H.; Woo, B.Y.; Hong, Y.D.; Noh, J.K.; Yi, D.K.; Kim, H.G.; Cho, J.Y. Anti-inflammatory effects of Huberia peruviana Cogn. methanol extract by inhibiting Src activity in the NF-kappaB pathway. Plants 2021, 10, 2335. [CrossRef] [PubMed]

24. Kim, S.A.; Oh, J.; Choi, S.R.; Lee, C.H.; Lee, B.H.; Lee, M.N.; Hossain, M.A.; Kim, J.H.; Lee, S.; Cho, J.Y. Anti-gastritis and anti-lung injury effects of pine tree ethanol extract targeting both NF-kappaB and AP-1 pathways. Molecules 2021, 26, 6275. [CrossRef]

25. Jo, M.; Lee, J.; Kim, H.G.; Kim, J.K.; Kim, H.; Shin, K.K.; Bach, T.T.; Eum, S.M.; Lee, J.S.; Choung, E.S.; et al. Anti-inflammatory effect of Barringtonia angusta methanol extract is mediated by targeting of Src in the NF-kappaB signalling pathway. Pharm. Biol. 2021, 59, 799-810. [CrossRef]

26. Korhonen, R.; Lahti, A.; Kankaanranta, H.; Moilanen, E. Nitric oxide production and signaling in inflammation. Curr. Drug Targets Inflamm. Allergy 2005, 4, 471-479. [CrossRef]

27. Liu, Y.; Krueger, J.G.; Bowcock, A.M. Psoriasis: Genetic associations and immune system changes. Genes Immun. 2007, 8 , 1-12. [CrossRef]

28. Sisto, M.; Ribatti, D.; Lisi, S. Understanding the complexity of Sjögren's syndrome: Remarkable progress in elucidating NF- $\kappa B$ mechanisms. J. Clin. Med. 2020, 9, 2821. [CrossRef]

29. Lawrence, T. The nuclear factor NF-kappaB pathway in inflammation. Cold Spring Harb. Perspect. Biol. 2009, 1, a001651. [CrossRef]

30. Hoesel, B.; Schmid, J.A. The complexity of NF-кB signaling in inflammation and cancer. Mol. Cancer 2013, 12, 86. [CrossRef]

31. Yang, W.S.; Jeong, D.; Nam, G.; Yi, Y.-S.; Yoon, D.H.; Kim, T.W.; Park, Y.C.; Hwang, H.; Rhee, M.H.; Hong, S.; et al. AP-1 pathwaytargeted inhibition of inflammatory responses in LPS-treated macrophages and $\mathrm{EtOH} / \mathrm{HCl}$-treated stomach by Archidendron clypearia methanol extract. J. Ethnopharmacol. 2013, 146, 637-644. [CrossRef] [PubMed]

32. Kim, H.G.; Yang, W.S.; Sung, G.H.; Kim, J.H.; Baek, G.S.; Kim, E.; Yang, S.; Park, Y.C.; Sung, J.M.; Yoon, D.H.; et al. IKK $\beta$-targeted anti-inflammatory activities of a butanol fraction of artificially cultivated Cordyceps pruinosa fruit bodies. Evid.-Based Complement. Altern. Med. 2014, 2014, 562467. [CrossRef] [PubMed]

33. Park, J.G.; Son, Y.-J.; Kim, M.-Y.; Cho, J.Y. Syk and IRAK1 contribute to immunopharmacological activities of anthraquinone-2carboxlic acid. Molecules 2016, 21, 809. [CrossRef] [PubMed]

34. Yang, W.S.; Jeong, D.; Yi, Y.-S.; Lee, B.-H.; Kim, T.W.; Htwe, K.M.; Kim, Y.-D.; Yoon, K.D.; Hong, S.; Lee, W.-S.; et al. Myrsine seguinii ethanolic extract and its active component quercetin inhibit macrophage activation and peritonitis induced by LPS by targeting to Syk/Src/IRAK-1. J. Ethnopharmacol. 2014, 151, 1165-1174. [CrossRef]

35. Jeong, H.Y.; Sung, G.-H.; Kim, J.H.; Yoon, J.Y.; Yang, Y.; Park, J.G.; Kim, S.H.; Yi, Y.-S.; Yang, W.S.; Yoon, D.H.; et al. Syk and Src are major pharmacological targets of a Cerbera manghas methanol extract with kaempferol-based anti-inflammatory activity. $J$. Ethnopharmacol. 2014, 151, 960-969. [CrossRef]

36. Hong, Y.H.; Kim, J.H.; Cho, J.Y. Ranunculus bulumei methanol extract exerts anti-inflammatory activity by targeting Src/Syk in NF- $\mathrm{KB}$ signaling. Biomolecules 2020, 10, 546. [CrossRef]

37. Yi, Y.-S.; Cho, J.Y.; Kim, D. Cerbera manghas methanol extract exerts anti-inflammatory activity by targeting c-Jun N-terminal kinase in the AP-1 pathway. J. Ethnopharmacol. 2016, 193, 387-396. [CrossRef]

38. González, M.I.; Martín-Duque, P.; Desco, M.; Salinas, B. Radioactive labeling of milk-derived xxosomes with 99mTc and in vivo tracking by SPECT imaging. Nanomaterials 2020, 10, 1062. [CrossRef]

39. Li, Z.-H.; Guo, H.; Xu, W.-B.; Ge, J.; Li, X.; Alimu, M.; He, D.-J. Rapid identification of flavonoid constituents directly from PTP1B inhibitive extract of raspberry (Rubus idaeus L.) leaves by HPLC-ESI-QTOF-MS-MS. J. Chromatogr. Sci. 2016, 54, 805-810. [CrossRef]

40. Kim, H.G.; Kim, M.-Y.; Cho, J.Y. Alisma canaliculatum ethanol extract suppresses inflammatory responses in LPS-stimulated macrophages, $\mathrm{HCl} / \mathrm{EtOH}$-induced gastritis, and DSS-triggered colitis by targeting Src/Syk and TAK1 activities. J. Ethnopharmacol. 2018, 219, 202-212. [CrossRef]

41. Qomaladewi, N.P.; Aziz, N.; Kim, M.Y.; Cho, J.Y. Piper cubeba L. methanol extract has anti-inflammatory activity targeting Src/Syk via NF-KB inhibition. Evid.-Based Complement. Altern. Med. 2019, 2019, 1548125. [CrossRef] [PubMed]

42. Lee, J.-O.; Yang, W.S.; Park, J.G.; Jeong, D.; Kim, H.G.; Yoon, K.D.; Aravinthan, A.; Kim, J.-H.; Kim, E.; Cho, J.Y. Src and Syk contribute to the anti-inflammatory activities of Achyranthes aspera ethanolic extract. J. Ethnopharmacol. 2017, 206, 1-7. [CrossRef]

43. Liu, T.; Li, X.; Wu, M.; Qin, L.; Chen, H.; Qian, P. Seneca valley virus 2C and 3C(pro) induce apoptosis via mitochondrion-mediated intrinsic pathway. Front. Microbiol. 2019, 10, 1202. [CrossRef]

44. Mishra, M.; Tiwari, S.; Gomes, A.V. Protein purification and analysis: Next generation Western blotting techniques. Expert Rev. Proteom. 2017, 14, 1037-1053. [CrossRef] [PubMed]

45. Yang, Y.; Yang, W.S.; Yu, T.; Yi, Y.-S.; Park, J.G.; Jeong, D.; Kim, J.H.; Oh, J.S.; Yoon, K.; Kim, J.-H.; et al. Novel anti-inflammatory function of NSC95397 by the suppression of multiple kinases. Biochem. Pharmacol. 2014, 88, 201-215. [CrossRef] [PubMed] 
46. Seok Yang, W.; Lee, J.; Woong Kim, T.; Hye Kim, J.; Lee, S.; Hee Rhee, M.; Hong, S.; Youl Cho, J. Src/NF-kB-targeted inhibition of LPS-induced macrophage activation and dextran sodium sulphate-induced colitis by Archidendron clypearia methanol extract. J. Ethnopharmacol. 2012, 142, 287-293. [CrossRef] [PubMed]

47. Shin, K.K.; Park, J.G.; Hong, Y.H.; Aziz, N.; Park, S.H.; Kim, S.; Kim, E.; Cho, J.Y. Anti-inflammatory effects of Licania macrocarpa Cuatrec methanol extract target Src- and TAK1-mediated pathways. Evid.-Based Complement. Altern. Med. 2019, 2019, 4873870. [CrossRef] 